\title{
Legitimita aristotelské inspirace v současné filozofii přátelství ${ }^{1}$
}

\author{
Legitimacy of Aristotelian Inspirations \\ in Contemporary Philosophy of Friendship
}

\author{
Matěj Troup
}

\begin{abstract}
Abstrakt
Východiskem článku je fakt, že současná anglicky psaná filozofie přátelství je silně inspirována aristotelskou teorií přátelství a považuje ji za nejvlivnější v rámci antických teorií. Toto východisko je v první části článku ilustrováno obecnými i konkrétními př́iklady.

Druhá a hlavní část článku si klade za cíl prověřit, zdali je Aristotelův primát v inspirativnosti současných myslitelů opodstatněný. To je provedeno na základě porovnání kvalit, kterými disponuje Aristotelova teorie přátelství a teorie dalších antických myslitelů - Platóna, Cicerona a Plútarcha.
\end{abstract}

\section{Klíčová slova}

filozofie přátelství, morální teorie, Aristotelés, Platón, Cicero, Plútarchos, Telferová, Badhwarová, Nehamas

\begin{abstract}
The starting point of the article is that the contemporary English written philosophy of friendship is strongly inspired by Aristotelian theory of friendship and considers this theory as the most influential among ancient theories. The starting point is illustrated in the first part of the article by general and specific examples.

Second and main part aims to examine justification of such a primacy of Aristotle's inspirations in contemporary philosophy of friendship. The verification is performed through

1 Tento článek shrnuje nejpodstatnější části mé diplomové práce TROUP, M. Aristotelské inspirace v modernich úvahách o prátelstvi [online]. Brno 2020. Dostupné z: 〈https://is.muni. $\mathrm{cz} / \mathrm{th} / \mathrm{ee} 4 \mathrm{al} />$. Diplomová práce. Masarykova univerzita, Filozofická fakulta.
\end{abstract}


comparison of qualities of Aristotle's theory and theories of other ancient philosophers Plato, Cicero and Plutarch.

\section{Keywords}

philosophy of friendship, moral theory, Aristotle, Plato, Cicero, Plutarch, Telfer, Badhwar, Nehamas

Předložený článek si klade za cíl ověřit, zda a nakolik jsou moderní inspirace Aristotelovou filozofií přátelství opodstatněné kvalitami této koncepce, a to ve srovnání s dalšími antickými koncepcemi přátelství. Moderními inspiracemi mám na mysli fakt, že současní myslitelé zabývající se přátelstvím² na Aristotela ve velké míře odkazují, rozvíjí jeho myšlenky nebo jeho myšlení kritizují, a tím zároveň budují teorii vlastní.

Článek obsahuje dvě části: 1) Doložení výchozí teze, že Aristotelova koncepce přátelství je skutečně pro současné anglofonní myslitele primárním inspiračním zdrojem, pokud jde o antické koncepce přátelství. 2) Analýzu kvalit Aristotelovy teorie přátelství a jejich srovnání s kvalitami teorií přátelství jiných antických myslitelů, jmenovitě Platóna, Cicerona a Plútarcha.

\section{Současná filozofie přátelství a Aristotelés}

Tato část článku má dostatečně ilustrovat, že se současní anglicky píšící autoři skutečně inspirují Aristotelovou koncepcí přátelství a že Aristotelés je z jejich pohledu nejvlivnějším antickým filozofem přátelství. To je z obecného hlediska patrné z následujících pasáží:

Víme o dvou autorech, kteří dominovali v diskuzi o přátelství po staletí, o Aristotelovi a Ciceronovi. ${ }^{3}$

Obecně se má za to, že Aristotelovo pojetí přátelství [...] představuje vrchol antického myšlení v oblasti přátelství. ${ }^{4}$

[...] dílo, které po mnohá století figurovalo jako hlavní zdroj odkazů pro diskuzi o přátelství, je Aristotelova Etika Nikomachova. V určitém smyslu se dá tvrdit, že

2 Tj. myslitelé tzv. filozofie přátelství, která se začala formovat přibližně od roku 1970.

3 SHKLAR, J. On Political Obligation..., s. 53-54.

4 STERN-GILLET, S. - GURTLER, G. M. (eds.) Ancient..., s. x (vlastní překlad). 
do dnešní doby v tomto tématu nebylo ani nemohlo být napsáno či vymyšleno nic, co by nezačínalo u Aristotela. ${ }^{5}$

Aristotelés, jehož spisy o přátelství mají do dnešního dne stále filozofický význam [...]. ${ }^{6}$

Pro většinu filozofie přátelství poskytuje Aristotelés prubířský kámen. Jeho příspěvek o přátelství, což se obecně tvrdí, je nejbystřejší analýzou přátelství v antické filozofii. ${ }^{7}$

[...] nejvíce kompletní a nejpodrobnější klasickou studii o přátelství nalezneme v Aristotelově Etice Nikomachově. ${ }^{8}$

Zdá se, že úvahy, jako jsou tyto [úvahy o morálce, existenci práv a altruismu pozn. aut.], podnítily k neobyčejnému současnému filozofickému zájmu o Aristotelovu morální filozofii, konkrétně o téma přátelství. ${ }^{9}$

Pro úplnost uvádím některé současné myslitele, kteří explicitně odkazují na Aristotela a využívají jeho dílo jako inspiraci pro své vlastní myšlenky.

5 GRAYLING, A. C. Friendship..., s. 6 (vlastní překlad).

6 VERNON, M. The Philosophy..., s. 2 (vlastní překlad).

7 Tamtéž, s. 170 (vlastní překlad).

8 PANGLE, L. Aristotle..., s. 2 (vlastní překlad).

9 Tamtéž, s. 4 (vlastní překlad).

Pokud půjdeme ještě dále a prozkoumáme obsah významných antologií současné anglicky psané filozofie přátelství, zjistíme následující:

V antologii Ancient and Medieval Concepts of Friendship (2014) nalezneme odkazy na Aristotela na 131 stranách; na Platóna na 93 stranách; na Cicerona na 62 stranách a na Plútarcha na 37 stranách.

V publikaci Thinking about Friendship: Historical and Contemporary Philosophical Perspectives (2013) nalezneme odkazy na Aristotela na 81 stranách; na Platóna na 31 stranách; na Cicerona na 17 stranách a na Plútarcha na 1 straně.

Ve sborníku Friendship: A History (2009) nalezneme odkazy na Aristotela na 49 stranách; na Platóna na 26 stranách; na Cicerona na 65 stranách a na Plútarcha na 9 stranách.

V monografii The Philosophy of Friendship (2005) nalezneme odkazy na Aristotela na 41 stranách; na Platóna na 23 stranách; na Cicerona na 7 stranách a na Plútarcha na 3 stranách. V publikaci Friendship: A Philosophical Reader (1993) nalezneme odkazy na Aristotela na 82 stranách; na Platóna na 8 stranách; na Cicerona na 8 stranách; na Plútarcha se zde vůbec neodkazuje. 
Za prvního současného myslitele, resp. myslitelku v oblasti přátelství je považována ${ }^{10}$ Elizabeth Telferová se svým článkem „Friendship“ (1970).

V tomto článku se objevují následující aristotelské motivy:

- Telferová polemizuje s myšlenkou, že skutečné přátelství může vzniknout jen mezi dobrými či morálními (tj. ctnostnými) lidmi (EN VIII, 1156b7-25), a nepovažuje morálnost jedince za nutný faktor pro vznik přátelství. ${ }^{11}$

- Myšlenka, že skutečného přítele ${ }^{12}$ máme rádi (zajímáme se o něj) kvưli němu samotnému, nikoliv kvưli nějakým nahodilým vlastnostem ( $E N$ VIII, 1156b7-30). Podle Telferové je tato úvaha chybná, pokud z ní vyplývá, že nahodilé vlastnosti nemohou být důvodem k př́telství, resp. je podle této autorky chybné uvažovat o ctnostech (povaze) jednotlivce jako o nutné vlastnosti pro vznik přátelství. Aristotelova úvaha je však podle ní správná ve dvou jiných ohledech. Za prvé jde o prvek náklonnosti (affection), což je ve zkratce iracionální popud k jiné osobě kvůli ní jakožto konkrétnímu individuu. Tato náklonnost nemusí nutně zmizet se změnou charakteru (povahy) přítele, což odpovídá výše uvedené Aristotelově tezi. Za druhé jde o fakt, že pokud máme zalíbení (liking) v př́íteli pro jeho vlastnosti (např. zdvořilost či vtipnost), nejde o tyto vlastnosti jakožto obecný typ (nemůžeme soubor těchto vlastností přiřadit jinému individuu pro identický efekt), nýbrž o tyto vlastnosti tohoto konkrétního individua. Jde tedy o určitou unikátní charakteristiku, což se opět shoduje s Aristotelem - máme rádi osobu pro její konkrétní jedinečné vlastnosti, pro ni samotnou. ${ }^{13}$

- Myšlenka, že význam přátelství spočívá v jeho přispění blahobytu pro společnost a zejména ve zprostředkování blaha a obohacení života jednotlivce. ${ }^{14}$ Při svém zkoumání Telferová vychází z Aristotelovy úvahy o potřebnosti přátelství pro blaženého (štastného) člověka. Podle Aristotela je přítel nejhodnotnějším konečným dobrem, ${ }^{15}$ a je tedy nutné, aby i blažená osoba $\mathrm{k}$ tomuto dobru (přátelství) měla přístup. Př́itel slouží jako druhé já, na nějž jsou aplikována dobra (např. pomoc),

10 Např. PAKALUK, M. Other Selves..., s. vii nebo BADHWAR, N. K. (ed.) Friendship: A Philosophical..., s. 2.

11 TELFER, E. Friendship..., s. 227.

12 Tj. takové přátelství, které není primárně založeno na profitu (užitek či slast).

13 Tamtéž, s. 228.

14 Tamtéž, s. 240-241.

15 Takové dobro, které již neslouží k získání jiných dober. Jde o opak instrumentálního dobra. 
z čehož plyne štěstí (slast) pro obě osoby (EN IX, 1169b4-1170b20). Telferová tuto myšlenku upřesňuje, když tvrdí, že člověk nepotřebuje teoreticky žádného přítele pro obdržení pomoci či jiného dobra, avšak přátelství je unikátní vztah, nebot jedině v něm můžeme získat specifická dobra (služby). ${ }^{16}$

- Poslední aristotelskou inspirací v tomto článku je myšlenka, že přátelství je v životě jednotlivce (a tím i společnosti) obohacujícím prvkem a nikdo by si nepřál žít život bez přátel, i kdyby se mu dostávalo všech ostatních dober (EN VIII, 1155a5-10). Podle Telferové nám přátelství umocňuje přístup k celé paletě emocí a pocitů (např. slast, strast, naděje, strach, zlost, hrdost), díky čemuž se cítíme "více naživu“. ${ }^{17}$

Dalším příkladem myslitelky navazující na Aristotela a reflektující jeho myšlení v teorii přátelství je Neera Kapur Badhwarová. ${ }^{18}$ Aristotelské motivy v jejím díle jsou následující:

- Badhwarová přejímá19 Aristotelovo základní dělení přátelství na přátelství o sobě (end friendship) a na instrumentální přátelství, což skutečně odpovídá aristotelskému přátelství založeném na ctnosti na jedné straně a přátelství pro užitek či rozkoš na straně druhé ( $E N$ VIII, 1156a5-1156b33).

- V článku „Friends as Ends in Themselves“ (1987) Badhwarová rozebírá vztah již výše zmíněného přátelství o sobě a přátelství instrumentálního, což je opět kontext pocházející od Aristotela. Její výchozí de-

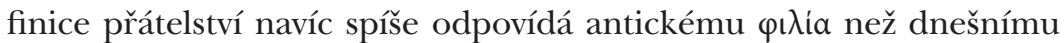
úžeji pojatému termínu přátelství. ${ }^{20}$ Badharowá svou výchozí definici výslovně nazývá aristotelskou definicí. ${ }^{21}$

- Identická aristotelská inspirace je patrná taktéž v článku „Why It Is Wrong to be Always Guided by the Best: Consequentialism and Friendship“ (1991), v němž Badhwarová zpochybňuje kompatibilitu konsekvencialismu a přátelství o sobě (end friendship).

16 Tamtéž, s. 238-239.

17 Tamtéž, s. 239-240.

18 Její příspěvek pro teorii přátelství spočívá v tom, že je editorkou citované antologie Friendship: A Philosophical Reader a autorkou většího množství článků zabývajících se filozofií přátelství.

19 BADHWAR, N. K. Friendship: A Philosophical..., s. 3.

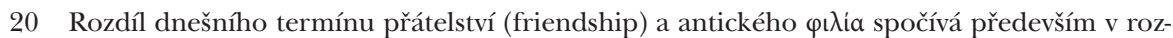
dílné extenzi. Pod $\varphi \imath \lambda i$ a spadají kromě přátelství také rodinné svazky, vztah pána a otroka, obchodní a politické vztahy a další.

21 BADHWAR, N. K. Friends as Ends..., s. 1. 
- Pro úplnost uvádím ještě následující články: „The Circumstances of Justice: Liberalism, Community, and Friendship“ (1993) ${ }^{22}$ a „Friendship and commercial societies“ (2008) $)^{23}$, v nichž Badhwarová opět odkazuje na Aristotela a používá jej jako oporu pro svůj výklad obdobným způsobem jako výše uvedené články.

Další významnou figurou v současné teorii přátelství je Alexander Nehamas, který (na rozdíl od výše uvedených) tématu přátelství věnoval celou svou knihu s názvem On friendship (2016). Také v jeho myšlení hrají aristotelské motivy zásadní roli:

- Nehamas mj. explicitně polemizuje s Aristotelovým esencialismem. Podle Nehamase se totiž nestáváme přítelem jiné osoby proto, že disponuje nějakou objektivně a nezávisle na nás existující ctností. Spíše si na této osobě ceníme určitých vlastností, které jsou nám subjektivně libé a které vůbec nemusejí být ctnostmi. Pokud tedy není nutnou podmínkou nějaká ctnost, nýbrž libovolná vlastnost, pak vyvstává otázka, jaký je rozdíl mezi láskou k někomu o sobě a láskou k někomu kvưli jeho slávě, bohatství, vzhledu atd. ${ }^{24}$

- Z Z hlediska aristotelského esencialismu je otázka řešena následovně: naše lidská přirozenost/povaha (nature) je založena na ctnostech. Pokud máme tedy rádi př́tele pro něj samého (pro jeho přirozenost/ povahu), máme jej rádi pro jeho ctnosti. To však Nehamas odmítá, protože nejsme schopni říct, na čem je tato přirozenost/povaha založena, resp. zda něco jako lidská přirozenost/povaha vůbec existuje. ${ }^{25}$

- Nehamas v podstatě rozšiřuje či přejímá aristotelskou představu (EN IX, 1169b4-1170b20) prrítele jakožto druhého já (friend is another self). Přítel neslouží pouze jako prostor pro sebereflexi a užitek, ale je přímo utvářejícím prvkem mého já, a podílí se tak na mé identitě. Pokud ztratím přítele, ztratím také část své identity (změním se). Nové přátelství znamená nový způsob, jak prožívat život. ${ }^{26}$

Nyní přejděme k ústřední otázce článku - je tato vlivnost a inspirativnost Aristotelovy filozofie přátelství věcně odůvodnitelná?

22 S. 219 a 235.

23 S. 311, 313, 316 a 320.

24 NEHAMAS, A. On friendship..., s. 28-29.

25 Tamtéž, s. 29.

26 Tamtéž, s. 203-205. 


\section{V čem spočívá primát Aristotelovy filozofie přátelství?}

V této části článku budu sledovat, v čem vyniká a př́ípadně v čem zaostává Aristotelova koncepce přátelství ve srovnání s koncepcemi Platóna, Cicerona a Plútarcha, ${ }^{27}$ a to z kvalitativního i kvantitativního hlediska. Srovnání nám ukáže, zda jsou moderní badatelé nakloněni právě aristotelské filozofii přátelství právem. U současných badatelů totiž nenalezneme žádné vysvětlení toho, proč je pro ně právě Aristotelova teorie přátelství v rámci dějin filozofie tak významná.

Pro následující komparaci volím tato kritéria: 1) Obsažnost - v rámci tohoto kritéria budu sledovat míru rozsahu dané koncepce a toho, jak detailně či komplexně daný myslitel zpracoval jednotlivé části tématu. 2) Systematičnost či formálnost výkladu - sledovat budu to, jak je daná teorie přátelství úplná, tj. nakolik mapuje dané téma v celé jeho šíri a nakolik je provázaná vnitřně a případně i s dalšími tématy. 3) Originalita teorie. 4) Poslední kritérium je syntézou tří předešlých kritérií a má zhodnotit společnou funkčnost obsahové i formální stránky dané teorie přátelství. Určitá teorie totiž může být např. vysoce systematická, ale obsahově velice stručná a neoriginální, či bohatá rozsahem a originalitou, ale absolutně nesystematická a nekoherentní atd.

Srovnání bude probíhat tak, že proti Aristotelově teorii postupně postavím teorii Platónovu, Ciceronovu a Plútarchovu, a podle výše uvedených kritérii jednotlivé teorie srovnám. Výsledkem bude odpověd’ na otázku, zdali je Aristotelova koncepce přátelství kvalitativně lepší než kterákoliv jiná porovnávaná koncepce.

\subsection{Aristotelés}

Pro analýzu aristotelské koncepce přátelství jsou významné zejména spisy etické: Etika Nikomachova (EN) a Etika Eudémova (EE), př́ípadně Politika a Rétorika. Úvahy o přátelství jsou v Aristotelově díle významnou součástí etické koncepce. ${ }^{28}$

1) Nejvýznamnějším prvkem Aristotelovy teorie přátelství je distinkce tří základních forem přátelství - pro ctnost, rozkoš a užitek. Aristotelés rozlišuje přátelství podle toho, zda jde o vztah motivovaný instrumentálně (rozkoš

27 Platón, Aristotelés, Cicero a Plútarchos jsou dle mého soudu jediní antičtí filozofové, u kterých se nám dochoval dostatečně ucelený výklad o přátelství.

28 Více o provázanosti problematiky přátelství a etiky ctnosti u Aristotela viz TROUP, M. Aristotelské..., s. 33-37. 
a užitek), či zcela altruisticky (ctnost). Ačkoliv považuje za jednoznačně nejlepší formu přátelství pro ctnost, věnuje nemalý prostor také charakteristice zbylých dvou forem (EN VIII 3, 1156a5-25; EE VII 2, 1236a30-b1). Aristotelés tedy neomezuje přátelství jen na vztah dokonale ctnostných a morálně dobrých lidí, ale přiznává jej také všem ostatním lidem.

Jeho charakteristika forem přátelství nespočívá jen v definování jednotlivých přátelství, ale pokračuje vysvětlením výhod a obtíží, které se s danými formami přátelství pojí. Pro každý druh přátelství také platí odlišné podmínky pro jeho zachování (např. EN VIII 4, 1156b5-35; 5, 1157a5-15; 10, 1159b12-23).

Ani jedna z forem nemusí být jednoznačně symetrickým vztahem vzhledem k motivaci pro přátelství, nebơ Aristotelés pragmaticky uvažuje také o smíšených typech přátelství, ve kterých je každý z přátel motivován jiným předmětem svého zalíbení. Stejně tak uvažuje o přátelství kvalitativně rozdílných jedinců z hlediska společenského postavení (EN VIII 8, 1158b1-30; VIII 15, 1162a35-1162b5).

Neméně důležitým motivem je představa ctnostného př́itele jakožto „druhého já“. Tato metafora vysvětluje nejpodstatnější význam přátelství pro dobrého člověka a zdůvodňuje, proč i absolutně dokonalý člověk má mít přítele (EN IX 4, 1166a10-35; EE VII 12, 1245a26-30).

Přátelství má podle Aristotela zcela nutný význam nejen pro ctnostné osoby, ale i pro všechny ostatní, a to na individuální i společenské úrovni ( $E N$ VIII 1, 1155a5-10; EE VII 1, 1234b31-1235a1). Přátelství má za následek družnost ve všech společenstvích. Díky družnosti drží společnost pohromadě a je v ní zaručena spravedlnost (EN IX 6, 1167b1-15).

V souhrnu je Aristotelova teorie přátelství svým rozsahem myšlenek a domýšlením různých vztahů velmi komplexní.

2) Ze systematického hlediska je Aristotelova koncepce přátelství velice konzistentní, ucelená a je explicitně vřazena do rozsáhlého systému etiky ctnosti. V obou Etikách se o přátelství mluví jako o nedílné součásti dobrého života člověka ( $E N$ VIII 1; EE VII 1). Přátelství je navázáno na ctnosti a vrcholný cíl lidského jednání - blaženost (EN IX 9). Pokud z Aristotelova etického systému vyloučíme jeho teorii přátelství, nebude již kompletní a nebude v něm zcela jasná úloha společnosti pro blaho jednotlivce.

Aristotelés ve svém výkladu velmi dbá na odlišení zásad pro dané formy přátelství. Pokud hovoří o nějakém problému či specifickém vztahu, má na paměti svou základní distinkci forem přátelství.

Z hlediska úplnosti je aristotelská teorie přátelství velmi uspokojivá, jelikož svým rozsahem pokrývá nejrůznější vztahy. Týká se tedy rozličných vztahů 
napříč společností i společnosti jako celku, nikoliv jen jednoho velmi specifického typu přátelství, což je pro ucelenou teorii důležité.

3) Aristotelova teorie přátelství je v mnohém originální a svébytná. I přes tento fakt lze vypozorovat určité vlivy, které Aristotelés přejímá od Platóna.

Je teoreticky možné, že typologie přátelství u Platóna mohla být alespoň z části inspirací pro Aristotelovu typologii. Platón ve Faidrovi (241c-d; 256ab; 256c-d) i Zákonech (837d-e a 838a-842a) rozlišuje přátelství pro dobro (ctnost), rozkoš a kombinaci obou předešlých, která ve Faidrovi vede k úctě mezi přáteli, v Zákonech je označena za nestabilní. Aristotelés hovoří naproti tomu o přátelství pro ctnost (charakter), rozkoš a užitek.

Když Aristotelés definuje přátelství jako vztah založený na vzájemné přízni, uvádí, že je nemožné, aby mohl být člověk přítelem neživé věci, jelikož v takovém případě je jakákoliv citová vzájemnost zcela vyloučena. Tato poznámka zřejmě reaguje na problém, který najdeme v Lysidovi (212d-e).

V Lysidovi (215a-b) se také objevuje teze, že dokonale dobrý člověk je absolutně soběstačný a přítel pro něj nemá žádný užitek, tudíž nemá důvod navazovat jakékoliv přátelství. Na tuto tezi pravděpodobně reaguje Aristotelés, když potřebu přátelství přisuzuje také dokonale blaženému člověku ( $E N$ IX 9, 1169b-1170b; EE VII 11, 1245b9-18).

4) Aristotelova teorie přátelství představuje obsahově velmi bohatý a systematicky koherentní celek, který je navíc součástí jeho etiky ctnosti, v níž je přátelství důležitým prvkem. Zda při koncipování teorie přátelství Aristotelés skutečně čerpal z Platóna, není jisté, nicméně se vypořádává s některými problémy, které Platón v Lysidovi uvádí, a možná částečně přejímá typologii forem přátelství.

\subsection{Platón}

Mezi relevantní platónské dialogy zabývající se (většinou jen zčásti) tématem přátelství/lásky patří: Lysis, Symposion, Faidros, Ústava a Zákony. Platónova koncepce přátelství obsahuje mnoho nejasností z hlediska systematičnosti a konzistence i z hlediska terminologie..$^{29}$

1) Platónova teorie přátelství je oproti Aristotelově teorii poměrně stručná a mírou rozsahu zaostává. Ačkoliv oba myslitelé nějakým způsobem odpovídají na otázku po povaze a významu přátelství pro jednotlivce i společenský celek, Platón v podstatě nedochází dále než ke stručné typologii přátelství

29 O problémech s Platónovou koncepcí přátelství detailně viz TROUP, M. Aristotelské..., s. 19-29. 
(Faidros a Zákony) ${ }^{30}$ a ke kontextuálně upozaděné ${ }^{31}$ stmelovací funkci občanského přátelství (např. Resp. V, 463e3-4; IX, 590d2-6 a Leg. I, 627e-628a; III, 693b-c; V, 748c).

Dialog Lysis, jehož ústředním tématem je právě přátelství, je z velké části inkonkluzivní. Pokud v něm Platón na některé otázky týkající se přátelství odpovídá, tak jen implicitně. Mnoho problémů z Lysida je nicméně řešeno ${ }^{32}$ ve Faidrovi (např. 255b, srov. s Lys. 214d-215a) a Zákonech (837b-d totéž), což bychom mohli považovat za uspokojivý prvek, pokud by se ovšem zejména typologie jednotlivých druhů přátelství v těchto dvou dialozích neodlišovala. ${ }^{33}$

Aristotelés i Platón předkládají typologii přátelství. Aristotelés uvažuje o všech typech podrobně, Platón se věnuje především přátelství pro ctnost, které upřednostňuje před ostatními, o ostatních mluví spíše s despektem, do hlubší analýzy typů se nepouští. I u Platóna však nalezneme alespoň zmínky o rozdílném trvání jednotlivých typů přátelství (napr. Phaedr. 256c-d).

Téma vhodného počtu přátel pro ctnostné či jakékoliv jiné přátelství u Platóna nenalezneme, stejně tak u něj nenalezneme podmínky či limity pro udržitelné přátelství.

Oba myslitelé hovoří o občanském přátelství, resp. o významu přátelství či družnosti pro fungování společnosti. Platón se však ve svých politických dialozích vyjadřuje o přátelství jen implicitně a nepodává ucelený výklad o významu přátelství pro společnost.

Svou stručností a menším tematickým rozsahem Platónova teorie přátelství za tou Aristotelovou zaostává.

2) U Platóna je hlavní formální problém v tom, že se minimálně z hlediska filozofie přátelství nejedná o systematického myslitele. Platónova stanoviska se napříč dialogy mění, z čehož vyplývá nemožnost provést konzistentní výklad jeho teorie. Při výkladu o jeho koncepci přátelství je to snad nejzřetelněji vidět na rozdílné funkci slova épwৎ ve Faidrovi a Zákonech. Obecným

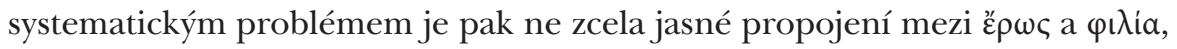
což vede k nejasné hranici mezi výkladem o lásce a přátelství.

30 Viz sekce 2.1, 3. kritérium.

31 Tím mám na mysli, že úvahy o přátelství představují v Platónových politických dialozích jen vedlejší téma. Proto Platón nemá potřebu objasňovat, co občanské přátelství je, nýbrž jen předpokládá občanské přátelství jako nutnou podmínku pro fungování obce.

32 Např. zdali je přátelství založeno na vzájemnosti nebo jaký užitek má přítel pro ctnostného člověka.

33 K rozdílné typologii viz TROUP, M. Aristotelské..., s. 32. 
Platón se vyjadřuje pozitivně převážně jen o přátelství pro ctnost, přátelství pro rozkoš ve Faidrovi i Zákonech či smíšenou formu přátelství v Zákonech nepovažuje za hodnotnou. U Aristotela naopak vidíme respekt ke všem formám přátelství, ačkoliv taktéž favorizuje pouze jeden typ (pro ctnost).

Návaznost Platónova pojetí přátelství na jiná témata je z větší části nejasná. Jelikož je Platón nesystematický myslitel, nemůžeme uvažovat o jeho teorii přátelství jako o součásti etického systému takovým zpơsobem, jako je tomu u Aristotela. Lze to jen částečně, a to u jeho koncepce občanského přátelství. Zejména v Ústavě, ale také v Zákonech je pospolitost občanů ideální obce zcela nutnou podmínkou pro fungování státního aparátu.

3) Platón je ze srovnávaných myslitelů nejstarší, tudíž tento bod vynechávám.

4) Ze srovnání vyplývá, že Platónovo pojetí přátelství je oproti Aristotelovu pojetí obsahově méně bohaté, není systematické a např́íc dialogy je nekonzistentní.

\subsection{Cicero}

Při analýze Ciceronovy koncepce přátelství je primárním zdrojem jeho dialog Laelius o prátelstvi (Laelius de amicitia; dále De amic.) a sekundárním pramenem spis $O$ povinnostech (De officiis; De offic.), který se věnuje povinnostem morálního člověka.

1) Ciceronovo pojetí přátelství je vztaženo zejména k nejlepší možné podobě přátelství, která je založena na podobnosti ctnostných charakterů přátel. Cicero takřka celý svůj výklad směřuje k předpisům, které mají člověka dovést ke ctnostnému přátelství (De amic. vi.22).

Pokud takovou koncepci porovnáme s Aristotelovou koncepcí, dojdeme k závěru, že Ciceronova koncepce přátelství se zaobírá jen jednou z částí, ${ }^{34}$ o nichž pojednává Aristotelés. Cicero hovoří téměř výhradně o přátelství pro ctnost, a to ještě v mnohem stručnější podobě než Aristotelés. Aristotelés pak nad rámec třech forem přátelství rozebírá i asymetrické či hybridní vztahy, což činí Cicero jen v omezené míře. Uvažuje totiž o vztahu společensky či ctnostně více a méně dokonalého jedince, nikoliv o vztahu dvou odlišných jedinců s jinými motivacemi (xix.69-xx.73; xxvi.97).

Cicero stejně jako Aristotelés uvažuje o významu přátelství pro společnost i jednotlivce (De offic. II.viii.; De amic. vii.23).

34 Můžeme říct, že z hlediska typologie druhů přátelství se zaobírá jen jednou třetinou. 
Z celkového hlediska je Aristotelova koncepce přátelství obsáhlejší rozsahem témat i podrobností, kterou se jim věnuje.

2) Z hlediska systematičnosti Ciceronovo pojetí přátelství v porovnání s Aristotelovým pojetím také neobstojí. Cicero není systematickým myslitelem, jeho etické poučky týkající se přátelství mají vést k ctnostnému a morálnímu životu jedince, nejsou psány za účelem podrobné analýzy přátelství. Nejedná se tedy o ucelený filozofický systém.

3) Ciceronova teorie přátelství se minimálně z části inspiruje aristotelskou teorií a přebírá od ní stěžejní principy a charakteristiky přátelství. Nicméně Cicero tak nečiní systematicky, nýbrž eklekticky vybírá jen určité myšlenky a nerozvádí je. Mezi evidentně neautentické myšlenky patří: metafora přítele jako druhého já (De amic. vi.22), časové prověřování přátelství (xxii.85), přátelství pro ctnost, které je vztahem pouze dobrých lidí (ix.32). Obecně, Ciceronova teorie přátelství nepřináší v rámci tématu nic nového, co bychom již v nějaké podobě nenašli u Aristotela.

4) Ciceronova teorie přátelství z obsahového hlediska jen částečně pokrývá teorii Aristotelovu, navíc nesystematickým způsobem a týká se v podstatě zcela elitářského př́stupu k přátelství, což z ní dělá dosti omezenou teorii. Do tématu navíc nepřispívá ničím originálním, jen částečně přejímá teorii Aristotela. V souhrnu Ciceronova teorie přátelství ničím nevyniká nad teorii Aristotelovu.

\subsection{Plútarchos}

Plútarchos je z filozofického hlediska považován za platónika, který usiloval o vytvoření koherentního systému na základě Platónova učení. ${ }^{35}$

Pro pochopení Plútarchovy teorie přátelství jsou podstatné některé spisy, které jsou součástí celku nazvaného Moralia. Těmito spisy jsou: Jak se pozná pochlebnik od př́tele (Quomodo adulator ab amico internoscatur; Adul.), Jak nám mohou být naši nepřátelé prospěšni (De capienda ex inimicis utilitate; De cap.), O prátelstvi s mnohými (De amicorum multitudine; De amic.) a O lásce mezi sourozenci (De fraterno amore).

1) Plútarchovo pojetí přátelství obsahuje v zásadě tytéž problémy jako pojetí Ciceronovo. Obecně je třeba říct, že se Plútarchos ve svém výkladu nepouští do detailní analýzy přátelství, ani pro něj není důležité mnohé myšlenky vysvětlovat.

35 KARAMANOLIS, G. Plutarch..., úvod a části 1. a 6. 
U Plútarcha (oproti Ciceronovu pojetí) se však setkáváme s detailnější analýzou dvou dílčích témat. Zaprvé jde o analýzu pochlebnictví, které Plútarchos charakterizuje jako falešné přátelství a kterému dává v rámci svých úvah o přátelství poměrně velký prostor (Adul. 49b-64e). Druhým tématem jsou výhody, jež mohou plynout z nepřátelského vztahu (De cap. 87d-88e). Plútarchos také pojednává o problému vhodného počtu přátel v dobrém životě, což je ale téma, které se nachází již u Aristotela (De amic. 95a-e).

Navzdory tomu, že se Plútarchos zaměřuje i na subtilnějš́ témata, je stále jeho přínos pro filozofii přátelství i rozsah jeho díla podřadný oproti přínosu a rozsahu Aristotelovy koncepce přátelství.

2) Z hlediska systematičnosti je Plútarchova teorie přátelství zhruba na stejné úrovni jako teorie Ciceronova. Jedná se o výklad laděný v hellénistickém duchu, tedy se záměrem vést člověka $\mathrm{k}$ dobrému životu - nejedná se o systematickou analýzu tématu, ale o rady pro dobrý život. Plútarchův výklad o přátelství proto nelze označit za ucelenou koncepci.

3) Za originální lze u Plútarcha považovat jednak analýzu pochlebnictví, která se u předešlých myslitelů neobjevuje, a také úvahy o nepřátelství a jeho možném prospěchu pro člověka. V obou případech jde o autentické myšlenky, které v Aristotelově teorii přátelství nenalezneme.

4) Z výše uvedeného je evidentní, že Aristotelské pojetí přátelství kvalitativně vyniká obsahem i systematičností nad Plútarchovo pojetí. Ačkoliv Plútarchos přináší do tématu některé originální prvky, jejich význam je spíše doplňkový a nepředstavují důvod, proč Plútarchův výklad upřednostnit před Aristotelovým.

\subsection{Zhodnocení}

Z mé komparace vyplývá, že ani jeden z porovnávaných myslitelů v souhrnu kritérií nepřekonává svou teorií přátelství teorii Aristotelovu.

Aristotelova teorie přátelství je zaměřena na společnost jako celek a neignoruje ani morálně méně kvalitní podoby přátelství, díky čemuž je obecnější a více pragmatickou teorií.

Dle mého soudu je Aristotelova teorie přátelství pro moderní badatele významná a vlivná právě proto, že v rámci antických teorií jako jediná analyzuje a promýšlí fenomén přátelství velmi široce a systematickým způsobem. Pokud totiž hledáme inspiraci v počátcích nějaké disciplíny či tématu, budeme volit takový výklad, který nám toho může nabídnout nejvíce a v nejsrozumitelnější formě. 
Je tedy vlivnost a inspirativnost Aristotelovy filozofie přátelství zdůvodnitelná? Z výše uvedené komparace jednoznačně vyplývá, že ano.

\section{Použitá literatura}

ARISTOTELÉS. Etika Nikomachova. Přeložil A. KŘÍŽ. Praha: Rezek ${ }^{3} 2009$.

ARISTOTLE. The Eudemian Ethics of Aristotle. Přeložil P. L. P. SIMPSON. New Brunswick: Transaction Publishers 2013.

BADHWAR, N. K. (ed.). Friendship: A Philosophical Reader. Cornell University Press 1993.

BADHWAR, N. K. Friends as Ends in Themselves, Philosophy and Phenomenological Research. 1987, 48(1), s. 1-23.

BADHWAR, N. K. Friendship and commercial societies. Politics Philosophy E Economics. 2008. 7(3), s. 301-326.

BADHWAR, N. K. The circumstances of justice: Pluralism, community, and friendship. Journal of Political Philosophy. 1993, 1(3), s. 250-276.

BADHWAR, N. K. Why it is wrong to be always guided by the best: Consequentialism and friendship. Ethics. 1991, 101(3), s. 483-504.

CAINE, B. (ed.). Friendship: A History. London: Equinox Press 2009.

CALUORI, D. (ed.). Thinking about friendship: Historical and contemporary philosophical perspectives. London: Palgrave Macmillan 2013.

CICERO. O povinnostech: rozprava o 3 knihách věnovaná synu Markovi. Praha: Svoboda 1970.

CICERO. Tuskulské hovory: Cato starši o stář́; Laelius o prátelství. Přeložil V. BAHNÍK. Praha: Svoboda 1976.

GRAESER, A. Řecká filosofie klasického obdobi: sofisté, Sókratés a sokratikové, Platón a Aristotelés. Praha: OIKOYMENH 2000.

GRAYLING, A. C. Friendship. London: Yale University Press 2013.

KARAMANOLIS, G. Plutarch. In Zalta, E. (ed.). The Stanford Encyclopedia of Philosophy [online]. Winter 2016 Edition [cit. 2019-11-15]. Dostupné z: 〈https://plato. stanford.edu/archives/win2016/entries/plutarch/>.

LONG, A. A. Hellénistická filosofie: stoikové, epikurejci, skeptikové. Praha: OIKOYMENH 2003.

NEHAMAS, A. On friendship. New York: Basic Books 2016.

PAKALUK, M. (ed.). Other Selves: Philosophers on Friendship. Indianapolis: Hackett Publishing Company 1991.

PANGLE, L. Aristotle and the Philosophy of Friendship. Cambridge: Cambridge University Press 2002.

PLATÓN. Charmidés; Lachés; Lysis; Theagés. Přeložil F. NOVOTNÝ. Praha: OIKOYMENH ${ }^{2} 1995$.

PLATÓN. Minós; Zákony; Epinomis; Listy; Výměry; O spravedlivu; O zdatnosti; Démodokos; Sisyfos; Eryxias; Axiochos; Ledñáček; Epigramy. Přeložil F. NOVOTNÝ. Praha: OIKOYMENH 2003.

PLATÓN. Parmenidés; Filébos; Symposion; Faidros; Alkibiadés I, II; Hipparchos; Milovnici. Přeložil F. NOVOTNÝ. Praha: OIKOYMENH 2003. 
PLATÓN. Ústava. Přeložil F. NOVOTNÝ. Praha: OIKOYMENH ${ }^{42005 .}$

PLÚTARCHOS. O lásce a přátelství. Přeložil V. BAHNÍK - Z. K. VYSOKÝ. Praha: Svoboda 1987.

PRESS, G. (ed.). The Continuum Companion to Plato. Continuum International Publishers.

SHKLAR, J. On Political Obligation. Ashenden S. - Hess A. (eds.). London: Yale University Press 2019.

STERN-GILLET, S. - GURTLER, G. M. (eds.). Ancient and Medieval Concepts of Friendship. New York: State University of New York Press 2014.

TELFER, E. Friendship. Proceedings of the Aristotelian Society. 1970, 71(1), s. 223-241.

TROUP, M. Aristotelské inspirace v modernich úvahách o prátelstvi [online]. Brno 2020.

Dostupné z: 〈https://is.muni.cz/th/ee4a1/>. Diplomová práce. Masarykova univerzita, Filozofická fakulta.

VERNON, M. The Philosophy of Friendship. London: Palgrave Macmillan 2014.

\section{Mgr. Matěj Troup}

Doktorand Katedry filozofie, Filozofická fakulta, Masarykova univerzita

Arna Nováka 1, 60200 Brno, Česká republika

428400@mail.muni.cz

Toto dílo Ize užít v souladu s licenčními podmínkami Creative Commons BY-NC-ND 4.0 International (https://creativecommons.org/licenses/by-nc-nd/4.0/legalcode). Uvedené se nevztahuje na díla či prvky (např. obrazovou či fotografickou dokumentaci), které jsou v díle užity na základě smluvní licence nebo výjimky či omezení příslušných práv. 
